Kosenko Aleksandra Petrovna,

Doctor of Economics, Associate Professor, Professor of the Department of Economics and Marketing, National Technical University "Kharkiv Polytechnic Institute" (Kharkiv, Ukraine);

Tkachev Maksim Mikhailovich,

Candidate of Economic Sciences, Associate Professor, Associate Professor of Department of Law, National Technical University "Kharkiv Polytechnic Institute" (Kharkiv, Ukraine);

Kobielieva Tatiana Aleksandrovna,

Candidate of Economic Sciences, Associate Professor, Associate Professor of Department of Business Administration and Personnel Management, National Technical University "Kharkiv Polytechnic Institute" (Kharkiv, Ukraine);

Tkacheva Nadezhda Petrovna,

Candidate of Economic Sciences, Associate Professor, Associate Professor of Department of Economics and Marketing, National Technical University "Kharkiv Polytechnic Institute" (Kharkiv, Ukraine)

\title{
DETERMINATION OF LOST PROFITS OF RIGHTHOLDERS FROM COUNTERFEIT GOODS
}

The processes of exclusive rights violation of the manufacturers of original (licensed) products on the technological market are investigated. It is proposed methodical approaches concerning economic valuation of the amount of lost profits of the rights holders (licensees) in violation of intellectual property rights, the amount of which is firstly connected by the authors with the degree of use the copyright of their manufacturing facilities. It is developed a block-structured approach to the definition of missed potential opportunities of right holders and it is proposed economic and mathematical models for their determination.

Keywords: enterprise potential, rights holders, counterfeit, exclusive rights, damages, lost profit.

DOI: 10.21272/mmi.2017.1-22

The relevance of the problem. An unauthorized reproduction of the results of intellectual activity of the industrial enterprises and their sales (counterfeit activity) cause significant damage to its owners, branches, consumers and the state. The reason for the spread of counterfeit products on a global scale is significant and continuously growing volume of markets of that property (especially software) and high profitability of illegal reproduction that affects the state of the industry and its sectors $[1 ; 2]$.

The production and market sale of counterfeit products damages [3; 4]:

- to companies producing original (licensed) products, as they lose additional income (lost profits), moreover, it additionally damages business reputation of the trademark;

- an illegal distribution of cheap products can reduce competition and, as a consequence, the development of a similar technology, and thereby slow down the emergence of innovation, the pace of technological progress;

- as counterfeiters work illegally, they do harm for the state in the form of nonpayment of taxes and excise taxes, they do damage for the reputation of the state;

- counterfeit (falsified) products can harm the health of consumers because of its low quality.

This situation makes research highly relevant and it is dedicated to the study and assessment of economic losses of copyright holders from infringement of their exclusive rights in the technology market.

Analysis of recent researches and publications. Theoretical and methodological foundations of 
the economy of counterfeiting activity in a certain way were developed in the research of domestic and foreign scientists, such as S.M. Illyashenko [1; 18], I.V. Gladenko [5; 6], A.M. Efimov [8], A.V. Kostin [11], D. Kozicki [12; 13], S.Y. Maksimova [14], P.G. Pererva [3; 4; 7; 10], N.I. Pogorelov [15; 22-24], I.Y. Polishchuk [16], V.L. Tovazhnianskyi [19], E.E. Jaskiewicz [21] etc.

In the economic sphere, the attention of researchers is mainly paid to the determination of the valuation of technology product and determination of the commercial potential for its commercialization or transfer $[10 ; 13 ; 15 ; 18 ; 19 ; 22]$. There are practically no fundamental research on the quantification of damages from the breach of the exclusive rights of original (licensed) products' manufacturers. The only exception is publications of A.V. Kostin [11], S.Y. Maksimova [14], I.Y. Polishchuk [16], E.E. Jaskiewicz [21], who mainly restricted in their recommendations by the staged questions.

Selection of the unsolved questions. Methods of struggle against counterfeit activities at the present time practically are not developed. They include legislative (enforcement of existing legislation), administrative (fines and confiscation of products), technical, economic and awareness-raising measures.

An important factor that hinders the fight against violations of exclusive rights is almost complete lack of scientifically-based methods of determining the economic losses incurred by copyright holders, and that does not allow relevant authorities to determine more or less exact values of economic loss. All that involves the development of an appropriate scientific base for the calculation of direct losses from counterfeit activities, and accompanying losses, lost profits and moral damage extent.

The main purpose of this article is further development of scientifically based methods and approaches to determine the value of economic losses incurred by producers of original products during violation of their exclusive rights in the technology market.

Research findings. Our studies indicate that loss of the right holders in the investigation of counterfeiting activity in the technology market (losses) can have both economic and legal nature.

Legal entities and private individuals have legal damages due to the actions of other persons and should be reimbursed in the force of law or contract. In most cases, the causes of damages in the legal sense are illegal actions that werevcaused by them. Losses caused by lawful actions, can be recovered as an exception in cases of extreme necessity (article 1066 of the Civil Code of Ukraine) from legal entity and private individual who caused the harm. Interesting is the interpretation of the essence of legal losses in terms of the effect they have on property relations included in the subject of civil rights.

Losses in economic value are broader concept. They include not only legal damages, but also other economic losses arising as a result of the actions of the business entity itself (for example, errors in the business management), and as a result of extraneous events and acts of third parties (for example, change of market conditions, price fluctuations, acts of public authorities). Another principal feature that distinguishes legal damages from losses in the economic sense, is the possibility of compensation of the first ones by the person who caused them. In this respect, the scientific interest is the idea that understands the losses that have value (monetary) terms, such a depreciation property benefit, which usually corresponds to the obligation of the person who caused the harm to compensate the damage, to make amends for the harmful consequences of their illegal actions. At the same time part of the economic losses is inevitably associated with risks, which are usual for entrepreneurial activity and the entrepreneurs themselves are forced to bear the burden of the losses, capping them at his own expense. Damages provided by law are enforced by the state and are the measure of civil liability.

The nature of the losses as an economic category, in our opinion, lies in the fact that in comparison with the optimal development of business processes, the entity incurs additional property losses or does not earn profit in full potential. This can be losses in the form of additional costs in the form of lost profit (unreceived income).

Lost profit is the income that a person could realistically obtain under normal circumstances, if the 
person's right had not been violated. In this case we are not talking about actual loss of legal entity or private individual that it has made or will make, and those revenues that it will receive less as a result of violations of their intellectual property rights. As evidenced by the practice of production and business activities in the field of technology products, loss of profits, or lost of profits is extremely difficult in calculations and provings. With the aim of obtaining the necessary for calculations information, it requires the examination of the amount of actual losses based on the analysis and research of the retrospective practice of similar violations, determining the terms of violations of the exclusive rights obtained by the offender of income, opportunities, and plans of the owner, as well as determining the presence and depth of the relationship among these factors.

This kind of common approach to the determining the amount of lost profits, in our opinion, requires some clarification. Without objecting future or past realization of the potential of the company it is still necessary to clarify: did the enterprise have these capabilities or does it have them? If the company has already completely deployed its production capacity, then what loss of revenue can be? There are not any possibilities for it. Another thing, when such production capabilities are in the enterprise. On this basis, we propose to determine the potential (maximum) profits of an enterprise $S F_{\text {max }_{+}}^{\text {pot }}$ (or $S F_{\text {max }_{t}}^{\text {vir }}$ ) for additional production and sale of this product, which can be calculated using the values of production capacity $B P_{t}$ or increased capacity of enterprises $B M_{t}$. An important role is given to the value of the coefficient of production capacities utilization of the enterprise $K_{\text {wikt }}^{\text {pot }}$ and its production capabilities $K_{\text {wik }}^{\text {vir }}$ for the manufacture of these products at the time period $t$.

Our studies indicate a low relevance of the foregoing premises as reserves of production capacity in many machine-building enterprises of Ukraine are still quite significant (Table 1).

Table 1 - Potential loss of profits in the studied enterprises (compiled by the authors based on data of enterprises)

\begin{tabular}{|l|l|c|c|c|}
\hline \multirow{2}{*}{ The company } & \multirow{2}{*}{$\begin{array}{c}\text { Type of production according to } \\
\text { which the calculation is made }\end{array}$} & \multicolumn{3}{c|}{$S F_{\text {max }_{t}}^{\text {pot }_{t}=B M_{t}\left(1-K_{\text {wik }_{t}}^{\text {vir }}\right)}$} \\
\cline { 3 - 5 } & Tractors & 2013 year & 2014 year & 2015 year \\
\hline JSC "HTZ" & Trucks & 0,62 & 0,54 & 0,56 \\
\hline JSC "KrAZ" & Cars & 0,73 & 0,34 & 0,43 \\
\hline PSC "ZAZ" & Filters for cars & 0,84 & 0,65 & 0,56 \\
\hline OOO "Feniks" & Brake pads & 0,91 & 0,87 & 0,85 \\
\hline OOO "DAFMI" & Auto parts & 0,69 & 0,63 & 0,92 \\
\hline PJSC "Krkz" & Dampers & 0,81 & 0,77 & 0,72 \\
\hline OOO "AGAT" & Protection of engine crankcase & 0,79 & 0,82 & 0,83 \\
\hline OOO "MAIL" & &
\end{tabular}

The structural model of the determination of the amount of lost profits of the rights holders from violations of their exclusive rights of $Z_{l p}$ is offered to use as (1):

$$
Z_{\text {lp }}=Z_{\text {lp.pr }}+Z_{\text {cr }}+Z_{\text {dostr }}+Z_{\text {sm.pr }}+Z_{\text {dow }}+Z_{f}+Z_{\text {lic }} \text {, }
$$

where $Z_{\text {.lp.pr }}$ - the loss of the licensor of the potential profit from the sale of additional units of higherquality original product at a higher price; $Z_{c r}$ - loss share of the target market and, accordingly, consumer demand for the original product; $Z_{\text {dostr }}$ - losses of the licensee (loss of benefit) from premature rupture of existing license agreements or reducing their volume; $Z_{\text {sm.pr }}$ - decrease of sales volume as a result of declining popularity and demand by consumers of original products; $Z_{\text {dow }}$ - reducing consumer confidence in producing original products as a result of more attractive cost characteristics of counterfeit 
products; $Z_{f}$ - losses from the failure of negotiations on the already generally agreed upon transactions for the supply of original products; $Z_{\text {lic }}$ - the damage from the failure of negotiations on already agreed upon deals for the sale of licenses to potential licensees.

Let us consider included in the formula (1) lost profits in more detail and form the methodological approaches to their definition.

Loss of the ability of the licensor to obtain additional income through the sale of additional units of higher-quality original product at a higher price of the Z.lp.pr can be estimated as follows (2):

$$
Z_{\text {lp.pr }}=N_{q}\left(P_{2}-P_{1}\right),
$$

where $N_{q}$ - the number of unsold products of the licensor at a higher price $P_{2} ; P_{1}$ - the current market price, which made the implementation of this product.

Important potential loss is the decrease in the share of the market, which was at the disposal of the owner of intellectual property, whose rights have been violated. The presence of this type of damages occurs in the case where the counterfeit product does not vary significantly in quality from the original. But for any product the market capacity has appropriate boundaries, which it is not so easy to extend. The emergence of further manufactured products with similar consumer properties will inevitably lead to certain negative producer impact: reducing the volume of sales of the original products and the creation of its surplus stocks; the need to reduce prices to eliminate excess inventories (according to the law of demand). Let us note, that in this case the capacity of the target market can not change, or can keep growth trend, but the relative proportion of the right holder (licensor and/or licensee) will decrease, will not increase or will increase at a slower pace.

Former lost abilities of the rights holder by reducing the proportion of the target market and, consequently, the loss of consumer demand for the original product $Z_{c r}$ resulting from unauthorized shipments of counterfeit products into the territory, which is protected by patent, and losses the right holder the opportunity to deliver a similar consignment over a period of time $T$, we propose to determine in the following way(3):

$$
Z_{c r}=\sum_{t=1}^{T} N_{c o n t r}^{t}\left(P_{1}^{t}-C_{1}^{t}\right) K_{t}^{n c}
$$

where $N_{\text {contr }}^{t}$ - the volumes of supply of counterfeit products in the $t$ year; $P_{1}{ }^{t}, C_{1}^{t}-$ respectively, the market price and the unit cost of production at the enterprises of a licensor or licensee in the $t$ year; $\left(P_{1}^{t}-C_{1}^{t}\right)$ - profit per unit of the original products if the supply was carried out independently by the patentee or licensee in the $t$ year; $K_{t}^{n c}$ - coefficient of building rates in the $t$-th year, which is used to bring the cost of lost profits of the previous period for each year t calculated for the year $T$, that is, the date of the evaluation $\left(K_{t}^{n c}=\frac{1}{K_{t}^{\text {disk }}}\right)$.

Using dependence (3) the authors carried out calculations of lost profits on some types of products, trademark holders of which are "DAFMI" and OOO "AGAT", which to the greatest extent were a subject of interest of contractors. The results of the calculations are presented in the Table 2.

The obtained values for loss of profits (Table 2) reproduce the lost opportunities of the right holder at the expense of reducing the share of the target market and, consequently, the loss of consumer demand for the original product $Z_{c r}$, resulting from unauthorized shipments of counterfeit products into the territory, which is protected by patent, and the losses the right holder the opportunity to deliver the same production batch for the current year. 
О.П. Косенко, М.М.Ткачов, Т.О. Кобєлєва, Н.П.Ткачова. Визначення упущеної вигоди правовласників від контрафактної продукції

Table 2 - The calculation of lost profits of manufacturers of original spare parts from counterfeit activities in 2015 (compiled by the authors based on data of enterprises)

\begin{tabular}{|c|c|c|c|c|c|c|c|c|}
\hline \multirow{3}{*}{ Statistics and indicators } & \multicolumn{8}{|c|}{ Auto parts manufacturers and their products } \\
\hline & \multicolumn{4}{|c|}{ OOO "DAFMl"* } & \multicolumn{4}{|c|}{ OOO "AGAT"*k } \\
\hline & D1 & D2 & D3 & D4 & A1 & A2 & A3 & A4 \\
\hline Output, $N_{\Sigma, \text { st. }}$ & 5000 & 8000 & 5000 & 7400 & 1800 & 2100 & 2200 & 2200 \\
\hline Sales, $N_{\text {реал., st. }}$ & 7500 & 10490 & 8200 & 11450 & 2870 & 3480 & 3450 & 3860 \\
\hline Stocks on $01.01 .15, C Z_{n}$, st. & 940 & 1430 & 750 & 1850 & 320 & 670 & 465 & 390 \\
\hline Stocks on 01.01.16, $C Z_{K}$, st. & 790 & 1240 & 820 & 1980 & 405 & 580 & 610 & 505 \\
\hline $\begin{array}{l}\text { The change in inventory } \\
\triangle C Z=C Z_{k}-C Z_{n}\end{array}$ & -150 & -190 & +70 & +130 & +85 & -90 & +145 & +115 \\
\hline $\begin{array}{l}\text { The volume replaced with counterfeit } \\
\text { demand } N_{\kappa \phi}=\left(N_{\text {real }}-N_{\Sigma} \pm \Delta C Z\right)\end{array}$ & 2350 & 2300 & 3270 & 4160 & 1155 & 1290 & 1395 & 1775 \\
\hline 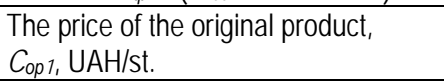 & 80 & 160 & 165 & 80 & 956 & 585 & 1300 & 988 \\
\hline $\begin{array}{l}\text { The cost of the original product, } \\
P_{o p 1,} \text { UAH/st. }\end{array}$ & 58 & 104 & 106 & 58 & 560 & 320 & 790 & 625 \\
\hline $\begin{array}{l}\text { The amount of potential income of the } \\
\text { copyright holder } C_{o p 1}, \mathrm{UAH} / \mathrm{st} \text {. }\end{array}$ & 188,0 & 368,0 & 539,5 & 334,4 & 1104,2 & 754,6 & 1813,5 & 1753,7 \\
\hline $\begin{array}{l}\text { The cost of potential additional selling } \\
C_{l p}=N_{k f} C_{o p 1} \text {, thousand UAH }\end{array}$ & 136,3 & 239,2 & 346,6 & 242,4 & 646,8 & 412,8 & 1102,1 & 1109,4 \\
\hline $\begin{array}{l}\text { The amount of lost profits due to the } \\
\text { reduction of the target market, } \\
Z_{p p}=D_{l p}-C_{l p} \text {, thousand UAH }\end{array}$ & 51,7 & 128,8 & 192,9 & 92,0 & 457,4 & 341,8 & 711,4 & 644,3 \\
\hline
\end{tabular}

Notes: * - products of OOO "DAFMl": D1 - front brake pads for Tavria, Slavuta; D2 - brake pads front for Lanos, Sens, Nexia, Matiz; D3 - ear brake pads for Tavria, Slavuta; D4 - brake pads rear for Lanos, Sens, Nexia, Matiz; ${ }^{* *}$ - products of OOO "AGAT": A1 - front shock absorber "AGAT", the STANDARD for cars Tavria, Slavuta, Tavria Nova, set of 2 st; A2 - rear shock, AGAT The STANDARD for cars Tavria, Slavuta, Tavria Nova, set of 2 st; A3 front shock absorber, AGAT for Lanos car Lanos, Sens, set of 2 st.; A4 - rear shock AGAT, for Lanos car Lanos, Sens, set of 2 st.; *** - according to estimates of experts

Lost profit from early termination of licensing agreements, according to the prevailing opinion, the most characteristic for the enterprises of the rightholder (licensor). However, according to the results of our research, these actions are not limited to only losses of the licensor, the loss of profit is inherent in the enterprise of the licensee. Loss of business opportunity licensee from early rupture of existing license agreements or partial implementation (use) $Z_{\text {dostr }}$ because of the supply of offender on the territory of their actions on counterfeit products or otherwise violating the patent rights of the owner in period $T$ we propose to determine using the analytical model (4):

$$
Z_{\text {dostr }} \sum_{t}^{T_{1}} \sum_{l 1}^{L}\left[\left(N_{n p_{t}}^{\prime} \cdot P_{1}^{\prime} \cdot K_{t}^{\text {disk }}\right)\left(1-R_{t}^{\prime}\right)\left(1-D_{t}^{\prime}\right)\right]
$$

where $N_{n p}^{\prime}$ - undelivered volume to the market of authentic product $l-m$ by licensee in the $t$ year, pieces.; $R_{t}-$ actual at the moment of calculations t the royalty rate at the first licensee; $T_{l}-$ the unused license period by the first licensee; $P l_{1}$ - market unit price of the licensed products in the $t$ year; $D_{t}^{\prime}$ - the share of tax deductions in the unit price of the licensed products of the licensee in the current time period $t$.

Counterfeit actions by unscrupulous market entities can have far-reaching prospects. As we have noted, consumers do not understand what and why, who is guilty, who is not guilty, and their actions can 
be unpredictable. As one of the possible consequences of such a situation in the market is the current reduction in sales of original products by reducing the popularity and demand by consumers of original products $Z_{\text {sm.pr. }}$ Moreover, this reduction should not be viewed as a substitution of original products, counterfeit (this is a separate item of loss), and as regardless of this additional current decrease in market sales original (licensed) products due to the psychological uncertainty of the consumer in production and market behavior of the copyright owner. Current exposure of the licensor in this case can be estimated using the following dependencies (5):

$$
Z_{\text {sm.pr. }}=\left(N_{o p}^{t-1}-N_{\text {contr }}^{t}-N_{o p}^{t}\right) P_{1}^{o p_{t}}\left(1-D_{t}\right)
$$

where $N_{o p}^{t-1}$ - volume of original (licensed) products, which was implemented by the right owner on the market in time period $(t-1)$, i.e. in the period preceding the current one; $N_{\text {contr }}^{t}-$ the amount of counterfeit goods that was implemented by infringers of the exclusive rights to market in current time period $t ; N_{\text {op }}^{t}$ - volume original (licensed) products, which was implemented by the right owner on the market in the current time period $t ; P_{1}^{o p} t_{t}$ - the market price of the units original (licensed) product in the current time period $t ; D_{t}$ - the share of tax deductions in the unit price original (licensed) product in the current time period $t$.

The current decrease in market sales of original (licensed) products due to the psychological uncertainty of the consumer in production and market behaviour of the right holder in the future in itself will not disappear, respectively, the market demand for these products will not return to its initial state. For the return of consumer confidence and to eliminate the negative impact of counterfeit products it is necessary time, in some cases quite much time. Therefore, the lost opportunity of the holders at the current time are not the last ones, they will in the future, but their size can vary as one or the other side (logical - to decrease losses and increase demand for products holders).

The presence of this type of damages occurs in the case when the counterfeit products have significant differences in quality from the original,which can cause the consumer some doubts about the honesty and charity of the manufacturer of products which he does not know and does not see the difference in the production of high-quality and low-quality products. As experience shows, consumers who will purchase a particular product or service, are almost not interested in the fact that this violated someone's exclusive rights or not, who is owner and who is a violator of human rights. The main goal of the consumer is to obtain the required product quality for a certain amount of the money. If consumers are not satisfied with the quality of the product, or the ratio of quality/price, in the future he is likely to refuse to purchase this brand, and its holder objective or not an objective will lose the consumer (this may be as a single specific user and a certain percentage of the target market).

The size of missed opportunities by reducing consumer confidence in manufacturers of original (licensed) products as a result of more attractive cost characteristics of counterfeit products $Z_{\text {dow }}$ is proposed to use as the following dependence (6):

$$
Z_{\text {dow }}=\sum_{t=1}^{T_{\text {dow }}}\left(N_{o p}^{t-1}-N_{\text {contr }}^{t}-N_{\text {op }}^{t}\right) P_{1}^{o p_{t}} K_{t}^{\text {disk }}\left(1-D_{t}\right)
$$

where $T_{\text {dow }}$ - the time it takes for the franchisor to return consumer confidence in original products (for time period $t=\left(T_{\text {dow }}+1\right)$ the value of $\left.Z_{\text {sm.pr }}=0\right) ; \quad K_{t}^{\text {disk }}$ - discount factor cash flows occurring at different times in the $t$ year for reduction of losses of the right holder at a future period to the time of the evaluation $t_{0 .}$ 
Significant lost opportunity, i.e. the potential loss of patent holders can $Z_{f}$ take place from a breakdown of negotiations and rejection of a potential buyer to enter into negotiated contracts for the supply of quantities of products made using the inventions (methods) that are protected by patents, as a result of the supply of offenders of counterfeit products or infringement of patent rights of owner over the period $T$.

Our research suggests that in the case of the failure of a potential buyer to enter into negotiated contracts for the supply of parties original (licensed) goods, in the target market there can be two most likely situations:

a) agreements for specified products with copyright holders are already made, but has not been paid by the potential buyers. In their rejection of product patent holders will get direct (real) losses that cannot be classified as lost profits;

b) losses from sold, but not manufactured products, the supply of which was provided to the consumer during the term $T_{f}$. In this case, the losses are not signs of real (as the products not yet manufactured) and can be attributed to the potential, that is, the block losses lost profits. Estimation of such losses, in our opinion, can be made using the following formula (7):

$$
Z_{f}=\sum_{t=1}^{T_{t}} N_{f}^{t}\left(P_{1}^{f_{t}}-C_{1}^{f_{t}}\right) \cdot K_{t}^{\text {disk }} \cdot\left(1-D_{t}^{f}\right)
$$

where $N_{f}^{t}$ - the volume sold to consumers original (licensed) products in the $t$ year, which has not been made by rights holders yet, from which the consumer refused in connection with the supply of the market segment the term of the license agreements of counterfeit goods; $P_{1}^{t_{t}}, C_{1}^{t_{t}}$ - in accordance with the contract price and unit cost made original (licensed) products from which the consumer (buyer) refused in the $t$ year; $K_{t}^{\text {disk }}$-- coefficient of discounting cash flows occurring at different times in the $t$-th year to bring the lost profits of the rights holders in a future period to the time of the assessment; $D_{t}^{f}$ - the share of tax deductions in the unit price, not manufactured, but sold to original (licensed) products in the $t$ year.

Loss of income or profits (lost profits) by the copyright owner due to the failure of entering into commercial agreements with potential licensees that are directly connected with the appearance in the target market of counterfeit (counterfeit) products, or use of the patented method of production is possible on site license, which is expected to issue a third party and the interest of which is from a third party as a result of actions of the offender was reduced or completely disappeared. A similar situation can occur when the opportunities of assignment of a patent for certain commercial conditions, but in the same circumstances and this can become impossible and can potentially lead to loss of potential opportunities available to the patentee of income (lost profits).

The potential loss from the failure of negotiations on the already agreed upon transactions sale of licenses to potential licensees $Z_{\text {lic }}$ is proposed to determine as the following dependencies.

Methodological recommendations for calculating this type of loss of the licensor can be reduced to the following form (8):

$$
Z_{\text {lic }}=\sum_{t}^{T_{1}} \sum_{l 1}^{L}\left[\left(N_{\mathrm{Hn}}^{\prime} \cdot P_{1}^{\prime} \cdot K_{t}^{\text {disk }}\right)\left(1-R_{t}^{\prime}\right)\left(1-D_{t}^{\prime}\right)\right]
$$

where $N_{H n}$ - volumes remain undelivered or to market licensed products I-m by licensee in the $t$ year; $R t$ - actual at the moment of calculations $t$ the royalty rate at the I licensee (determined using the 
average values of royalty); $T_{I}$ - planned term of the license by the first licensee; $P_{1}^{\prime}$ - the market price of units of licensed products of the first licensee in the $t$ year; $D_{t}^{l}$ - the share of tax deductions in the unit price of the licensed products of the first licensee in the time period $t$.

It should be noted that as the offender can be not only some known or unknown firm that produces and supplies the market with counterfeit products, but also directly closest partner of the right holder or his licensee. It is known that in any license agreement there are granted boundaries to licensee exclusive rights to use the patent. If the licensee use these rights, knowledge and experience beyond the provided by him pursuant to the license agreement, the territory, time, volume of production and the type of license, it is a direct violation of patent rights of the owner and caused him damages or lost profit shall be compensated by the offender. The mechanism of such a compensation, in our view, is not fundamentally different from the considered above us and can (optionally) include a variety of informed us of the damages and loss of profits.

Conclusions. Studies indicate that currently the level of the violation of exclusive rights of innovation and intellectual activities of creative workers (counterfeiting) in various types of products entered the industrial character. The volume of counterfeit goods in certain sectors of industrial production in the world, in Europe and in our country is comparable with the volume of legal production, and in some cases even exceeds it. The analysis of the content and nature of the informal economy has led to the conclusion that the central place in the criminal economy, as the most important component of the informal economy, is the market of counterfeit goods.

It was developed methodological guidelines on economic valuation of the amount of lost profits of the rights holders for violation of their exclusive rights, the amount of which for the first time by the authors is related to the degree of use the copyright of their manufacturing facilities.

Prospects for further research. Further research should be linked with the development of methodological provisions for the assessment of direct and indirect economic losses of copyright holders in violation of their exclusive rights by unscrupulous entities target market. It is necessary to conduct research according to the moral damage, which, in our opinion, is the illegal activities of bad actors in the technological marketplace. These areas of formation of losses from infringements of the exclusive rights are no less interesting for investigation and urgently require the development of methodical approaches to the estimation of their sizes.

1. Маркетинг. Менеджмент. Інновації : монографрія / С.М.Ілляшенко, П.Г.Перерва та ін. / за ред. д.е.н., проф. C.М. Ілляшенка. - Суми : ТОВ "Друкарський дім "Папірус", 2010. - 621 с.

2. Кобєлєва Т.О. Електротехнічна галузь України: сучасний стан та перспективи розвитку // Т.О. Кобєлєва // Вісник НТУ “ХПІ". - Харків, 2011. - № 26. - С. 34-43.

3. Перерва П.Г. Економіка і маркетинг виробничо-підприємницької діяльності : навч. посібник / за ред. проф. Перерви П.Г., проф. Гаврись О.М., проф. Погорєлова М.І. - Харків : НТУ “ХПІ”, 2004. - 640 с.

4. Перерва П.Г. Трудоустройство без проблем (искусство самомаркетинга) / П.Г.Перерва. - Х. : Фактор, 2009. $480 \mathrm{c}$.

5. Гладенко І.В. Моніторинг інноваційної діяльності: інтерпретація результатів / П.Г. Перерва, І.В. Гладенко // Маркетинг і менеджмент інновацій. - 2010. - № 2. - С.108-116.

6. Косенко А.П. Экономическая оценка инновационного потенциала : монография / А.П. Косенко, Д. Коциски, О.И. Маслак, П.Г. Перерва, Д. Сакай / под ред. проф. Перервы П.Г. и проф. Коциски Д. - Харьков-Мишкольц : НТУ "ХПИ", Мишкольц. техн. ун-т, 2008. - 170 с.

7. Перерва П.Г. Визначення ризику оцінки стану кон'юнктури вітчизняного ринку асинхронних двигунів / П.Г. Перерва, Т.О. Кобєлєва // Маркетинг і менеджмент інновацій. - 2012. - № 1. - С. 79-88.

8. Ефимов А.Н. Оценка ущерба от распространения контрафактных копий программ [Электронный ресурс] / А.Н. Ефимов // Московский оценщик. - 2000. - № 5. - Режим доступа: http://www.valnet.ru/m7-26.phtml.

9. Перерва П.Г. Экономика и управление инновационной деятельностью : учебник / под ред. проф. Перервы П.Г., проф. Вороновского Г.К., проф. Меховича С.А., проф. Погорелова Н.И. - Харьков : НТУ “ХПИ”, 2009. - 1203 с.

10. Косенко О.П. Кон'юнктура технологічного ринку: оцінка ризиків комерціалізації об'єктів інтелектуальної власності / 
О.П. Косенко, Т.О. Кобєлєва, П.Г. Перерва // Вісник НТУ “ХПІ".- Харків : НТУ “ХПІ”, 2014.- № 33 (1076).- С. 76-87.

11. Костин А.В. Оценка убытков правообладателей товарных знаков. Обоснование размера убытков при возникновении споров / А.В. Костин // ИС. Промышленная собственность. - М. : 2007, - № 11. - С.12-20.

12. Коциски Д. Стратегічне управління виробничим потенціалом і підвищення конкурентоспроможності підприємства / Д. Коциски, П.Г. Перерва, А.П. Косенко // Вісник НТУ "ХПІ". Технічний прогрес і ефективність виробництва. 2010. - № 62. - C. 112-118.

13. Kocziszky G. Technology transfer / P.G. Pererva, G. Kocziszky, D. Szakaly, M. Somosi Veres. - Kharkiv-Miskolc : NTU "KhPl", 2012. $-668 \mathrm{p}$

14. Максимов С.Й. Підходи та методи визначення розміру збитків внаслідок порушення авторських прав на комп'ютерні програми [Електронний ресурс] / С.Й. Максимов, І.Ю. Поліщук. - Режим доступу: file:///C:/Users/PGP/Downloads/krise_2013_58(1)_51.pdf.

15. Погорелов М.І. Управління персоналом та економіка праці / М.І. Погорєлов, П.Г. Перерва, С.М. Погорєлов та ін. // за ред. проф. Погорелова М.І., проф. Перерви П.Г., доц. Погорєлова С.М., доц. Косенко О.П. - Х. : Щедра садиба плюс, 2015. $-521 \mathrm{c}$.

16. Полищук И.Ю. Основные подходы, которые применяются при расчете размера ущерба при нарушениях авторских прав на компьютерные программы [Электронный ресурс] / И.Ю. Полищук. - Режим доступа: http://intelect.org.ua/sites/defaultffiles/doklad polishchuk.pdf.

17. Проблеми і перспективи ринково-орієнтованого управління інноваційним розвитком : монографія / С.М. Ілляшенко, П.Г. Перерва, Н.П. Ткачова, О.П. Косенко та ін. / за ред. д.е.н., профресора С.М. Ілляшенка. - Суми : ТОВ "Друкарський дім "Папірус", 2011. - 644 с.

18. Механізм управління потенціалом інноваційного розвитку промислових підприємств : монограсія / Ю.С. Шипуліна, С.М. Ілляшенко, П.Г. Перерва, О.П. Косенко та ін. ; за ред. к.е.н., доц. Ю.С. Шипуліної. - Суми : ТОВ "ДД "Папірус", 2012. - 458 с.

19. Товажнянський В.Л. Антикризовий механізм сталого розвитку підприємства: монографія / В.Л. Товажнянський, П.Г. Перерва, Т.О. Кобєлєва, Н.П. Ткачова ; ред.: П.Г.Перерва. - Х. : Віровець А.П. : Апостроф, 2012. - 703 с.

20. Кобєлєва Т.О. Методичні засади моніторингу кон'юнктури ринку асинхронних електродвигунів / Т.О.Кобєлєва // Управління розвитком : зб. наук. праць. - Харків : ХНЕУ. - 2011. - № 4(101). - С.258-260.

21. Яскевич Е.Е. Систематизация методов оценки убытков правообладателей ПО для ЭВМ от контрафакции / Е.Е. Яскевич, Е.И. Володенкова // Интеллектуальная собственность. Авторское право и смежные права. - Москва : ООО Издательский Дом "Интелектуальная пресса", 2013. - № 3 - С. 36-49.

22. Управление инновационной деятельностью: в 3 ч. Ч. І. Основы инновационного менеджмента и экономики инноваций / П.Г. Перерва, С.Н. Глаголев, С.А. Мехович и др. ; под общ. ред. П.Г. Перервы, С.Н. Глаголева. - Белгород; Харьков : Изд-во БГТУ, 2012. - 545 с.

23. Управление инновационной деятельностью: в 3 ч. Ч. ІІ. Управление научными исследованиями, маркетинг и коммерциализация инноваций / П.Г. Перерва, С.Н. Глаголев, С.А. Мехович и др. ; под общ. ред. П.Г. Перервы, С.Н. Глаголева. - Белгород; Харьков : Изд-во БГТУ, 2012. - 426 с.

24. Управление инновационной деятельностью: в 3 ч. Ч.ІІІ. Организация подготовки специалистов для инновационной экономики / П.Г.Перерва, С.Н.Глаголев, С.А.Мехович и др. / под общ. ред. П.Г. Перервы, С.Н. Глаголева. Белгород; Харьков : Изд-во БГТУ, 2012. - 454 с.

1. Illyashenko S.M., Pererva P.G. ta in. (2010). Marketynh. Menedzhment. Innovatsii [Marketing. Management. Innovations]. Sumy: TOV "Drukarskyi dim "Papirus" [in Ukrainian].

2. Kobyelyeva, T.O. (2011). Elektrotekhnichna haluz Ukrainy: suchasnyi stan ta perspektyvy rozvytku [Electrical industry of Ukraine: current state and development prospects]. Visnyk NTU "KhPI", 26, 34-43 [in Ukrainian].

3. Pererva, P.G., Gavris O.M., \& Pogorelov, M.I. (2004). Ekonomika i marketinh virobnycho-pidpryiemnitskoi diialnosti [Economics and marketing production and business activities]. Kharkiv: NTU "KhPl" [in Ukrainian].

4. Pererva, P.G. (2009). Trudoustroistvo bez problem (iskusstvo samomarketinga) [Work without problems (the art of selfmarketing)]. Kharkov: Faktor [in Russian].

5. Gladenko, I.V., \& Pererva P.G. (2010). Monitorynh innovatsiinoi diialnosti: interpretatsiia rezultativ [Monitoring of innovative activity: interpretation of results]. Marketing i menedzhment innovatsiy - Marketing and Management of Innovations, 2, 108-116 [in Ukrainian].

6. Kosenko, A.P., Kotsiski, D., Maslak, O.I., Pererva, \& P.G., Sakay, D. (2009). Ekonomicheskaia otsenka innovatsionnoho potentsiala [Economic evaluation of innovative potential]. Kharkov-Mishkolts: NTU "HPI", Mishkolts.tehn.un-t. [in Russian].

7. Pererva, P.G., \& Kobylyeva T.O. (2012). Viznachennia ryzyku otsInki stanu koniunktury vltchiznianoho rynku asinhronnih dviguniv [The definition of risk assessment of the situation of the domestic market asynchronous motors]. Marketing and Management Innovation - Marketing and Management of Innovations,1, $79-88$ [in Ukrainian].

8. Efimov, A.N. (2000). Otsenka ushcherba ot rasprostranenyia kontrafaktnikh kopyi prohramm [Assessment of the damage caused by the proliferation of counterfeit copies of software]. Moskovskyi otsenshchyk - Moscow appraiser, 5. Retrieved from http://www.valnet.ru/m7-26.phtml [in Russian].

9. Pererva, P.G., Voronovskii, G.K., \& Pogorelov, N.I. (2009). Ekonomika i upravleniie innovatsionnoi deiatelnostiu 
[Economics and management of innovative activities]. Kharkov: NTU "KhPl" [in Russian].

10. Kosenko, O.P., Kobyelyeva, T.O., \& Pererva, P.G. (2014). Koniunktura tekhnolohichnoho rynku: otsinka ryzykiv komertsializatsiyi obiektiv intelektuanoi vlasnosti [Conditions of market process: risk assessment commercialization of intellectual property]. Visnyk NTU "KhPI" - Bulletin of the NTU "HPI", 33 (1076), 76-87 [in Ukrainian].

11. Kostyn, A.V. (2007). Otsenka ubytkov pravoobladatelei tovarnikh znakov. Obosnovanye razmera ubytkov pry voznyknovenyy sporov [Estimation of losses trademark owners. Rationale for the size of losses in the event of disputes] Promyshlennaia sobstvennost - IP. Industrial Property, 11, 12-20 [in Russian].

12. Kotsysky, D., Pererva, P.G. \& Kosenko, A.P. (2010). Stratehichne upravlinnia vyrobnychym potentsialom $i$ pidvyshchennya konkurentospromozhnosti pidpryyemstva [Strategic management of production potential and improve the competitiveness of enterprises]. Visnyk NTU "KhPl" - , 62, 112-118 [in Ukrainian].

13. Pererva, P.G.. Kozicki, D., Sakai, D., \& Veresna, M. Somosi. (2012). Transfer texnolohii [Transfer of technologies]. Kharkiv: Virovets A.P. "Apostrof" H. : Virovets A. P. "Apostrophe" [in Ukrainian].

14. Maksymov, S.I., \& Polishchuk, I.Yu. (2013). Pidkhody ta metody vyznachennia rozmiru zbytkiv vnaslidok porushennia avtorskykh prav na kompiuterni prohramy [Approaches and methods for determining the amount of loss due to copyright infringement of computer software]. Retrieved from file:///C:/Users/PGP/Downloads/krise_2013_58(1)_51.pdf [in Ukrainian].

15. Pogorelov, M.I., Pererva, P.G., \& Pogorelov S.M. (2015). Upravlinnya personalom ta ekonomika pratsi [Personnel management and labor Economics]. Kharkiv: Shchedra sadiba plyus [inUkrainian].

16. Polyshchuk, I.Yu. (n.d.). Osnovnie podkhodi, kotorie prymeniaiutsia pry raschete razmera ushcherba pry narushenyiakh avtorskykh prav na kompiuternie prohrammi [The main approaches that are used in calculating the amount of damages for violations of the copyright on computer programs]. intelect.org.ua. Retrieved from http://intelect.org.ua/sites/default/files/doklad_polishchuk.pdf [in Ukrainian].

17. Illyashenko, S.M., Pererva, P.G., Tkachova, N.P., Kosenko, O.P. et al. (2011). Problemy i perspektyvy rynkovooriyentovanogo upravlinnya innovacijnym rozvytkom: monografiya [Problems and prospects of market-oriented innovative development management]. Sumy: TOV "Drukarskyi dim "Papirus" [in Ukrainian].

18. Shypulina, Yu.S., Illyashenko, S.M., \& Pererva, P.G. (2012). Mekhanizm upravlinnia potentsialom innovaciinoho rozvytku romyslovykh pidpryyemstv [The management mechanism of innovative potential development of industrial enterprises]. Sumy: TOV "DD "Papirus".

19. Tovazhnianskyi, V.L., Pererva, P.G., Kobielieva, T.O., \& Tkachova, N.P. (2012). Antykryzovyi mekhanizm staloho rozvytku pidpryiemstva [Crisis mechanism for sustainable enterprise development]. Kharkiv: Virovets A.P. : Apostrof [in Ukrainian].

20. Kobeleva, T.O. (2011) Metodichni zasady monltoringu koniunkturi rinku asinhronnih elektrodviguniv [Methodical principles of monitoring of market of asynchronous electric motors]. Upravlinnia rozvytkom - Development Management, 4(101), 258-260 [in Ukrainian].

21. Yaskevych, E.E., \& Volodenkova, E.Y. (2013). Systematyzatsyia metodov otsenky ubitkov pravoobladatelei PO dlia EVM ot kontrafaktsii [Ordering of loss assessment methods holders of software for computers from counterfeiting]. Intellektualnaia sobstvennost. Avtorskoe pravo y smezhnie prava - Intellectual property. Copyright and related rights, 3, 36-49 [in Russian].

22. Pererva, P.G., Glagolev, S.N., \& Mekhovich, S.A. et al. (2012). Upravleniye innovatsionnoy deyatelnostyu [Management of innovative activity]. Osnovy innovatsionnogo menedzhmenta $i$ ekonomiki innovatsiy. Belgorod; Kharkov: Izd-vo BGTU [in Russian].

23. Pererva, P.G., Glagolev, S.N., Mekhovich, S.A. et al. (2012). Upravleniye innovatsionnoy deyatelnostyu [Management of innovative activity]. Upravleniye nauchnymi issledovaniyami. marketing i kommertsializatsiya innovatsiy. Belgorod; Kharkov: Izd-vo BGTU [in Russian].

24. Pererva, P.G., Glagolev, S.N., Mekhovich, S.A. et al. (2012). Upravleniye innovatsionnoy deyatelnostyu [Management of innovative activity]. Organizatsiya podgotovki spetsialistov dlya innovatsionnoy ekonomiki. Belgorod; Kharkov: Izd-vo BGTU [in Russian].

0.П. Косенко, д-р екон. наук, доцент, професор кафедри економіки і маркетингу, НТУ "Харківський політехнічний інститут" (м. Харків, Україна);

М.М. Ткачов, канд. екон. наук, доцент, доцент кафедри права, НТУ "Харківський політехнічний інститут" (м. Харків, Україна);

T.O. Кобєлєва, канд. екон. наук, доцент, доцент кафедри організації виробництва та управління персоналом, НТУ "Харківський політехнічний інститут" (м. Харків, Україна);

Н.П. Ткачова, канд. екон. наук, доцент, доцент кафедри економіки і маркетингу, НТУ "Харківський політехнічний інститут" (м. Харків, Україна)

Визначення упущеної вигоди правовласників від контрафактної продукції

Розглянуто процеси порушення виключних прав виробників оригінальної (ліцензійноі) продукції на технологічному ринку. Запропоновано методичні підходи щодо економічної оцінки розміру упущеної вигоди правовласників (ліцензіатів) при порушенні прав інтелектуальної власності, розмір якої авторами вперше пов'язане з ступенем використання правовласником своїх виробничих потужностей. Розроблено блочно-структурний підхід до визначення упущених 
О.П. Косенко, М.М.Ткачов, Т.О. Кобєлєва, Н.П.Ткачова. Визначення упущеної вигоди правовласників від контрафактної продукції

потенційних можливостей правовласників та запропоновано економіко-математичні моделі їх визначення.

Ключові слова: потенціал підприємства, правовласники, контрафакт, виключні права, збитки, упущена вигода.

А.П. Косенко, д-р экон. наук, доцент, професор кафедры экономики и маркетинга, НТУ "Харьковский политехнический институт" (г. Харьков, Украина);

М.M. Ткачев, канд. экон. наук, доцент, доцент кафедры права, НТУ "Харьковский политехнический институт" (г. Харьков, Украина);

T.A. Кобелева, канд. экон. наук, доцент, доцент кафедры организации производства и управления персоналом, НТУ "Харьковский политехнический институт" (г. Харьков, Украина);

Н.П. Ткачева, канд. экон. наук, доцент, доцент кафедры экономики и маркетинга, НТУ "Харьковский политехнический институт" (г. Харьков, Украина)

Определение упущенной выгоды правообладателяй от контрафактной продукции

Рассмотрены процессы нарушения исключительных прав производителей оригинальной (лицензионной) продукции на технологическом рынке. Предложены методические подходы к экономической оценки размера упущенной выгоды правообладателей (лицензиатов) при нарушении прав интеллектуальной собственности, размер которой авторами впервые связано со степенью использования правообладателем своих производственных мощностей. Разработан блочно-структурный подход к определению упущенных потенциальных возможностей правообладателей и предложены экономико-математические модели их определения.

Ключевые слова: потенциал предприятия, правообладатели, контрафракт, исключительные права, убытки, упущенная выгода.

Отримано 09.12.2016р. 